\title{
A kiadókKal kötött Read and Publish SZERZŐDÉSEK, ÉS A NYÍLT HOZZÁFÉRÉSÜ PUBLIKÁLÁS HAZAI LEHETŐSÉGEI
}

\section{GaÁlné KaLydy DóRa}

Számba véve a nyílt tudományhoz kapcsolódó hazai gyakorlatokat, kiemelten kell foglalkoznunk az országos licenc szerződések keretén belül „kifizetett” publikációs díjakkal, melyeket az Elektronikus Információszolgáltatás (EISZ) Nemzeti Program tud érvényesíteni a konzorciumi tagintézmények javára és érdekében.

A 2001 óta működő EISZ Nemzeti Program a 1079/2012. (III.28.) kormányhatározat ${ }^{1}$ alapján 2012 januárjától az MTA Könyvtár és Információs Központon keresztül biztosítja az előfizetői kör tagjai számára a hozzáférést elektronikus tudományos tartalmakhoz nemzeti licensz vásárlásával. Az EISZ kínálatában több mint 70 szakirodalmi adatbázis érhető el 2021-ben. Tartalmát tekintve az átfogó, minden tudományterületre kiterjedő, interdiszciplináris adatbázisok mellett különféle szakadatbázisok is elérhetőek a rendszerben.

A program stratégiai céljai a széleskörű kutatástámogató szolgáltatás biztosítása, amely az elektronikus tudományos tartalomhoz való hozzáférés mellett az Open Access publikálás lehetőségét is kínálja a hazai kutatási és felsőoktatási szféra számára a hazai innováció támogatása és a magyar tudományos eredmények nemzetközi láthatóságának erősítése érdekében.

A projekt eredményeként a hazai szakkönyvtári hálózat folyamatos hozzáférést biztosít a kutatói közösség számára a kurrens tudományos tartalmakhoz és aktívan támogatja a kutatók publikálási tevékenységét. A teljes szövegü adatbázisok mellett a bibliográfiai és hivatkozáskereső adatbázisok segítik a szakirodalmi áttekintéseket és

1 Magyar Közlöny: http://www.kozlonyok.hu/ 
lehetőséget biztosítanak az intézmények tudományos működésének összehasonlítására.

Az EISZ Titkárság kezdetektől kereste az Open Access országos megvalósításának módját, azonban az első ún. Read and Publish megállapodásra csak 2018. évben került sor a Taylor and Francis kiadóval ${ }^{2}$.

A Read and Publish szerződéseket sokszor átmeneti szerződéseknek is hívjuk, ezek a szerződések arra hivatottak, hogy a résztvevőket átvezessék a kizárólag előfizetési díj megfizetéséből a kizárólag publikációs díj fizetésébe. Ezek az átmeneti szerződések egyszerre tartalmaznak előfizetési díjat, mely alapján a tudományos cikkeket olvasni lehet, és egyszerre biztosítanak publikációs lehetőséget megfelelő APC (Article Processing Charge - cikk feldolgozási díj) befizetésével, melynek eredményeképpen az így megjelent cikkek bárki számára nyílt hozzáféréssel elérhetők, letölthetők és olvashatók lesznek. Célunk az, hogy a Read and Publish díj együtt nem haladhatja meg az eredeti előfizetési (subscription) díjat. Az évek múlásával az arányoknak változniuk kell, a nagyobb összegű előfizetési díj csökken, ezzel párhuzamosan a publikációs díj megnő, amíg el nem érünk abba a kánaánba, ahol már csak publikációs díjat fizetnek a konzorciumi tagok, akik a befizetett összeg fejében jogosultak a publikálásra.

Az EISZ keretein belül külön-külön konzorcium áll fel egy-egy adtabázis elérésére. Azok az intézmények kutatói, oktatói, amelyek olyan konzorciumban vesznek részt, olyan szerződésbe fizetnek önrészt, amelyek nemcsak előfizetési díjat, hanem publikációs díjat is tartalmaznak, azon intézmény oktatói, kutatói jogosultak publikációjukat az adott kiadó által kínált teljesen $\mathrm{OA}$ vagy hibrid ${ }^{3}$ folyóiratokban megjelentetni.

2 Taylor and Francis szerződés: http://eisz.mtak.hu/images/szerzodesek/TF_2018.pdf

3 A folyóiratban vannak nyílt hozzáféréssel bárhonnan elérhetô cikkek és vannak olyan zárt cikkek, melyek csak előfizetéssel érhetők el. 
Ezek az APC díjak a nemzetközi kiadóknál 1.000 eurótól egészen 12.000 euróig rúghatnak a kiadó meghatározása alapján. A legtöbb kiadó pontosan megállapítja az APC díjra fordítható keretösszeget, az így megjelenő publikációk számát, külön a teljes (Fully) Open Access, külön a hibrid lapok vonatkozásában.

Miért jó ez a kiadónak, egyetemnek, országnak ...?

Az egyetemek és kutatóintézetek munkatársai mindig is publikáltak, az elmúlt évtizedeben kialakult „Publish or Parish” (publikálj vagy dögölj meg) kifejezés valóban jól tükrözi a kutatók és oktatók előmenetelért folytatott publikációs csatáját. A kutatók intézményének, az egyetemeknek és kutatóintézeteknek is érdeke a minél több publikáció, hiszen az intézmény tudományos kibocsátását is mérik világ,- illetve országos szinten. Az intézmények rangsorolása több összetevő eredménye, ebben a versenyben kiemeleten fontos szerepet játszik az intézmény munkatársainak publikációs száma, Hirschindexe, az intézményhez affiliált szerzőkre való hivatkozások száma. A rangsorokon kívül az eddigi gyakorlat szerint az intézmények kutatástámogatási finanszírozása is nagyban függött a tudományos kibocsátások mennyiségétől és minőségétől.

Általánosságban elfogadott, kutatásokon alapuló tény, hogy a nyílt hozzáféréssel megjelent cikkek láthatósága és a rájuk való hivatkozások száma magasabb, mint az előfizetéses folyóiratokban megjelent publikációké. ${ }^{4}$ Tehát az intézményeknek egyik oldalról érdeke, hogy minél több az intézményhez affiliált szerző cikke nyílt hozzáféréssel jelenjen meg. Ugyanakkor a szóban forgó szerződések esetében jelenleg még (ki tudja, meddig) fizetjük az előfizetési díjat is és az APC díjat is. Annak ellenére, hogy az intézmények számára a nyílt hozzáférésű publikációk megjelenése tudományértékelés szempontjából pozitív, a finanszírozás oldaláról még sok esetben megoldatlan kérdés a hihetetlen

4 https://en.wikipedia.org/wiki/Open_access (utolsó megtekintés: 2021. 07. 24.) A kötetünkben olvasható Soós Sándor és Kiss Anna tanulmánya, amely megerősíti a hipotézist. 
magas APC díjak miatt, melyek a tudományos információellátást századok óta végző könyvtárak tiltakozása ellenére is folyamatosan emelkednek.

A nemzeti tudományos kibocsátásunk minél nagyobb láthatósága létkérdés és nemzetstratégiai kérdés is. $\mathrm{Az}$, hogy kinek a nevéhez kapcsolódik egy-egy tudományos felfedezés, nem elhanyagolható, ismerve a Bolyai János-féle nemeuklideszi geometriára vonatkozó leírás körüli kérdésfeltevéseket. A tudományos világ sokáig vitatta, hogy Bolyai János vagy Nyikolaj Ivanovics Lobacsevszkij nevéhez füződik a felfedezés, melyet mi magyarok egyértelműen Bolyai Jánosnak tulajdonítunk annak ellenére, hogy lehetséges: hogy egymástól függetlenül jutottak ugyanarra a következtetésre. A tudományos világban a mai napig is, sőt talán jobban, mint bármikor, létkérdés, hogy ki mikor publikál egy-egy újdonságot vagy új ismérvet. Ha országosan tudjuk támogatni és átlátni, hogy mely intézményből milyen publikációk kerülnek ki, az segíti az innovációért és kutatásáért felelős országos vezetőket a döntéshozatalban és a tudományos marketingben. Hasznos és előremutató lenne, ha a magyar nyílt hozzáférésű publikációk számontartását és finanszírozását ilyen módon központilag tudnánk adminisztrálni. Ez a fajta centralizáció a központosítás jó formája. Szintén országos érdek füződik az állami pénzekből finanszírozott kutatások eredményeinek nyílt hozzáférésű publikációjához. Ma már minden kutatási pályázat (OTKA, Bolyai stb.) előírása, hogy az adott pályázati ciklus eredményeit nyílt hozzáférés biztosításával publikálni kell. (Ez természetesen lehet monográfia vagy cikk nyomtatott és elektronikus megjelenése repozitóriumokon keresztül.) A döntés, hogy mely intézmény mit és milyen folyóiratban publikál, minden esetben az adott intézmény döntési hatáskörében kell, hogy maradjon.

A tudományos információ birtoklása és közzététele nemcsak üzleti, hanem hatalmi kérdés is. ${ }^{5}$ Mára egyértelművé vált, hogy azok a kiadók, akik a kezdeti kockázatot felvállalták a nyílt hozzáférésű lapok

5 Monok István, Új hatalmi viszonyok a tudományos információk megosztásában = Könyvtári(?) Problémák, Budapest, MTA KIK, 2020, 19-29. 
indításával, nyertesek a tudományos közlemények kiadásának piacán. $\mathrm{Az}$ APC díjak folyamatos emelésével bizonyosan fedezik nemcsak az adott cikk elektronikus kiadási költségét, hanem számos egyéb költséget is, hiszen a lektorálást (peer review) honorárium nélkül végzik az adott tudományos terület képviselői. Ezenkívül pedig a profitorientált kiadók (nem az egyetemi kiadók) a teljesen nyílt hozzáférésű folyóiratok mellett meghagyták a hibrid és az előfizetéses folyóiratok megjelentetését is. Sok szempontból a nyílt hozzáférés mozgalom a tudományos előmenetelért folytatott küzdelem ördögi körének csapdájába esett, hiszen a tudományos világ ranking szemlélete meghatározza, hogy mi tudományos az Impakt Faktor (IF) mutatószámmal', és elvárja a tudományos világ, hogy aki fokozatot szeretne lépni, minél több olyan lapban publikáljon, melynek magas az IF mutatója. Ezzel ellehetetlenítették a teljesen OA folyóiratok indulását, hiszen sok kutató nem akart és/vagy nem tudott 0 IF folyóiratban publikálni, hiszen azzal az ő tudományterülete nem számol, akármilyen nagy szenzációt publikálna, az előmenetelébe nem számít. A tudományos világ belső hatalmi harcai blokkolják a tudományos folyóiratok nyílt hozzáférésűvé válását azzal, hogy elfogadták az üzleti világ érdekeit érvényesítő tudományelemzési módszereket.

Az EISZ Nemzeti Programban nincs két egyforma átmeneti szerződés a nyílt hozzáférésű publikációk szempontjából. A Magyar Tudományos Akadémia Könyvtár és Információs Központ 11 kiadóval kötött Read and Publish szerződést az Elektronikus Információszolgáltatás Nemzeti Program keretében 2021-ben. Általánosságban a kiadók a nyílt hozzáférésű kvótát (akár pénzben adják meg, akár megjelentethető cikkek számában) az alapján határozzák meg, hogy az adott ország kutatói mennyit publikáltak a kiadónál az elmúlt 1-2-3 évben. A 11 kiadóból három kiadó (Akadémiai Kiadó, Cambridge University Press, Royal Society of Chemistry) kínálja korlátlan számú publikáció

6 Az IF azt mutatja, hogy az előző kétéves időtartamban a folyóiratban lévő cikkekre mennyien hivatkoztak. Minél magasabb az IF szám, annál szívesebben publikálnak benne a szerzők. Bizonyos tudományterületeken előírás, hogy mennyi IF-t kell gyűjteni és ezt, teljesen helytelenül, azonosítják a szerzővel. 
megjelentetését, természetesen, ha a cikk megfelel a kiadó által felállított minőségbiztosítási kritériumoknak. Ezek a kiadók nem határoznak meg sem pénzügyi, sem számbeli korlátot, kizárólag a lektorálási feltételeknek kell megfelelni. A három kiadó nagyon különböző szempontokat mérlegelt döntésének meghozatalakor: a CUP először 2021-ben tette korlátlanná a megjelenő cikkek számát. A döntés megértéséhez látnunk kell, hogy 2020-ban a szerződésben rögzített 30 cikk helyett 17 cikk jelent meg a konzorciumi szerzőktől. A RSC igen szűk tudományterületet foglal magában, a konzorciumban összesen négy magyar intézmény van. 2020-ban egyetlen magyar szerzőjü cikk jelent meg nyílt hozzáféréssel a RSC lapjaiban, vagyis ők nem kockáztatnak igazából azzal, ha azt mondják, „korlátlan számú magyar kutató publikálhat”. Az Akadémiai Kiadó folyóiratai népszerűek. Itt jelenik meg a legtöbb intézményi (egyetemi és kutatóintézeti) folyóirat. 2020-ban 622 tanulmány jelent meg nyílt hozzáféréssel az előfizetői kör munkatársaitól.

A többi nyolc kiadóval kötött megállapodásban rögzítettük, hogy milyen összegért hány cikk jelenhet meg. 2020-ban két kiadónál merítettük ki a rendelkezésre álló kvótákat, a Wileynál októberre elértük a szerződött 230 cikket, a Springer Nature kiadónál pedig a teljesen (fully) OA cikkek kvótája merült ki novemberre (26l cikk), decemberben pedig elértük a maximum, 601 hibrid folyóiratokban megjelenő cikkek számát. Statisztikai szempontból a leghasználtabb adatbázis a 40 intézményt magában foglaló Science Direct konzorcium folyóiratcsomagja (Elsevier) 1000 OA publikálási kvótát tartalmazott, az elfogadott cikkek száma 771 volt 2020-ban.

Az átmeneti szerződésekkel kapcsolatban összefoglalóan elmondhatjuk, hogy 2020-ról 2021-re csekély előrelépés látható, egy kiadóval bővült (Oxford University Press) az OA lehetőséget biztosító kiadók száma, illetve a Cambridge University Press bővítette korlátlanra a publikációs lehetőséget. Sok esetben a kiadók nem az Open Access mozgalom elvárásai és követelményei alapján biztosítják a publikálási lehetőséget, hanem az előfizetésen felül plusz szolgáltatásként értelmezik. 
Ezekben az esetekben az EISZ Program nem köt szerződést, nem „vásárol” publikációkat, hiszen a kutatástámogatás egyik meghatározó trendjéhez csatlakozva az EISZ is elkötelezett a nyílt hozzáférés teljes átállása mellett, nem támogatjuk a tudományos tartalmak többszöri megvásárlását. Célunk, hogy lehetőségeinkhez képest, sürgessük a nyílt hozzáférés elterjedését, a tudományos információk megosztását. Dolgozunk azoknak a lehetőségeknek a megteremtésén, hogy a magyarországi kiadókkal is hasonló szerződéseket köthessünk, támogatva ezzel a magyar tudományos nyelv megtartását, illetve a hazai kiadók modernizálását. 


\section{Open Science \\ NYÍLT TUDOMÁNY MAGYAR SZEMMEL}


A Magyar Tudományos Akadémia Könyvtárának Közleményei Publicationes Bibliothecae Academiae Scientiarum Hungaricae

$45(120)$
UJ SOROZAT

SOROZATSZERKESZTő

GaÁlné Kalydy Dóra 


\section{Open Science \\ NYÍLT TUDOMÁNY MAGYAR SZEMMEL}

Magyar Tudományos Akadémia

KöNYVTÁr ÉS InFORMÁcIÓs KözPONT

BUDAPEST 2021 


\author{
Szerkesztette \\ GaÁlné Kalydy DóRA \\ Anyanyelvi lektor \\ MóNOK MÁRIA \\ Az irodalomjegyzékeket készítette \\ BudAI-KirÁLY TÍmEA \\ Tipográfia és tördelés \\ VAs ViKTória \\ ISBN 978-963-7451-73-7 \\ ISSN 0133-8862 \\ DOI 10.36820/MTAKIK.KOZL.2021.OpenS
}

Felelős kiadó: az MTA Könyvtár és Információs Központ főigazgatója

Nyomta és kötötte az Alföldi Nyomda Zrt., Debrecen

Felelős vezető: GYöRGy GÉzA vezérigazgató

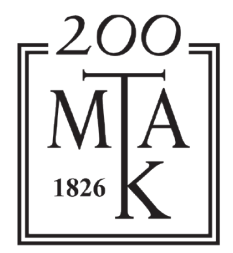

Megjelent a Nemzeti Kulturális Alap támogatásával

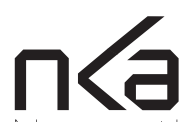

Nemzeti Kulturális Alap 


\section{TARTALOM}

\section{Monok István}

Cui bono, seu cui prodest?

Holl András

A tudományos szakkönyvtárak és a nyílt tudomány

(Open Science)

GaÁlnÉ Kalydy Dóra

A kiadókkal kötött Read and Publish szerződések, és a nyílt hozzáférésű publikálás hazai lehetőségei

Soós SÁndor, Kiss AnNA

Az „Open Access-előnyök" megnyilvánulása

a hazai tudásprodukcióban: bibliometriai hatásvizsgálat

61

\section{GaÁlné Kalydy Dóra}

A közösségi tudomány

\section{Tiberius Ignat}

What motivates us to develop the

Focus on Open Science series?

\section{Hoczopán Szabolcs, Molnár Tamás}

Az egyetemi könyvtárak szerepe a nyílt tudomány

mozgalom elterjesztésében

\section{Holl ANDrás}

Az MTA KIK gyakorlata a nyílt tudomány támogatásában $\quad 161$

A kötetben szereplő tanulmányok szerzői

A Magyar Tudományos Akadémia Könyvtárának

Közleményei, Új Sorozat közelmúltban megjelent kötetei 